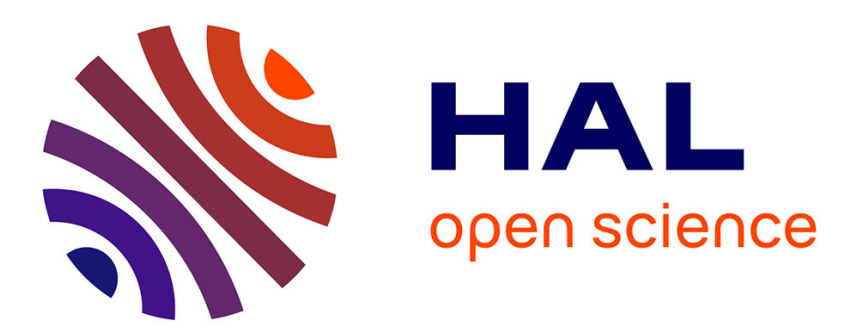

\title{
Experiencing the past in virtual reality A virtual reality event for the French National Days of Archaeology
}

Ronan Gaugne, Gaétan Le Cloirec, Jean-Baptiste Barreau, Valérie Gouranton

\section{To cite this version:}

Ronan Gaugne, Gaétan Le Cloirec, Jean-Baptiste Barreau, Valérie Gouranton. Experiencing the past in virtual reality A virtual reality event for the French National Days of Archaeology. 4th IEEE International Conference on Cognitive Infocommunications, 2013, Budapest, Hungary. pp.1-6. hal00916741

\section{HAL Id: hal-00916741 \\ https://hal.science/hal-00916741}

Submitted on 10 Dec 2013

HAL is a multi-disciplinary open access archive for the deposit and dissemination of scientific research documents, whether they are published or not. The documents may come from teaching and research institutions in France or abroad, or from public or private research centers.
L'archive ouverte pluridisciplinaire HAL, est destinée au dépôt et à la diffusion de documents scientifiques de niveau recherche, publiés ou non, émanant des établissements d'enseignement et de recherche français ou étrangers, des laboratoires publics ou privés. 


\section{Experiencing the past in virtual reality}

\section{A virtual reality event for the French National Days of Archaeology}

\author{
Ronan Gaugne \\ Université Rennes 1/IRISA-Inria \\ Rennes, France \\ Jean-Baptiste Barreau \\ CNRS/CReAAH \\ Rennes, France
}

\author{
Gaétan Le Cloirec \\ Inrap/CReAAH \\ Rennes, France
}

\author{
Valérie Gouranton \\ Insa Rennes/IRISA-Inria \\ Rennes, France
}

\begin{abstract}
This document reports a public exhibition organized during the French National Days of Archaeology, that is the result of an interdisciplinary collaboration between archaeologists and computer scientists, centered on the immersive virtual reality platform Immersia, a node of the European Visionair project. This public exhibition had three main goals: (i) presentating our interdisciplinary collaboration, (ii) communicating on the scientific results of this collaboration, and (iii) offering an immersive experience in the past for visitors. This paper presents the scientific context of the event, its organization, and a discussion on feedbacks.
\end{abstract}

Keywords-Virtual reality, archaeology, digital heritage, scientific mediation.

\section{INTRODUCTION}

In the context of the French Days of Archeology, the research organization WDCAH, West Digital Conservatory of Archaeological Heritage [1], presented an immersive archeological reconstitution to scholar students and public visitors using virtual reality techniques. The WDCAH organization is an association between archaeologists from CReAAH (French acronym for Research Center in Archaeology, Achaeoscience and History) and computer scientists from IRISA (French acronym for Research Institute in Computer Science and Random Systems) which targets the reconstitution of archaeological sites using virtual reality. These reconstitutions rely on the technological platform Immersia which allows to immerse a user in a large virtual universe.

There has been a great deal of effort to communicate archaeological and historical heritage to a large public through various interactive digital media such as web [9], second life environments [8], or touchpads [10]. The use of immersive virtual reality technology for public exhibition remains limited, mainly because of the underlying technical complexity, and also because of the cost of such facilities. An interesting

This work is partially funded by the European project Visionair under grant agreement 262044 and by the Université Européenne de Bretagne (UEB). example of such approach is presented in Christou et al. [11] where an immersive CAVE-like structure combined with haptic devices and 3D sound is used for pedagogic intentions in a museum exhibition.

The purpose of the underlying work presented in this paper was to build a 1:1 scale reconstitution of a disappeared GalloRoman villa in order to validate archaeological hypotheses, and better understand the operation of the global site. Virtual reality technology combined with the use of a large immersive platform made this project attainable [5].

\section{CONTEXT OF THE EVENT}

\section{A. West Digital Conservatory for Archaeological Heritage}

WDCAH, is a French research organization whose aim is to both ensure the preservation of digital archaeological data, and deliver expertise in production, analysis, visualization and virtual reality exploration techniques. This interdisciplinary project gathers engineers and researchers in archaeology, computer science, virtual reality and 3D interaction with virtual environments. The major objectives of this conservatory project are: (i) sustainable and centralized safeguarding and archiving of $2 \mathrm{D} / 3 \mathrm{D}$ data produced by the archaeological community; (ii) free access to metadata; (iii) secure access to data for the different actors involved in scientific projects and (iv) the support and advice for these actors in the $3 \mathrm{D}$ data production and exploration through the latest digital technologies, modeling tools and virtual reality systems.

\section{B. Immersia platform}

The immersive platform of the IRISA computer science laboratory is a large virtual-reality facility dedicated to realtime, multimodal (vision, sound, haptic, BCI) and immersive interaction. It hosts experiments using interactive and collaborative virtual-reality applications.

Images are rendered on four glass screens, a front one, two sides and a ground with an overall dimension of $10 \mathrm{~m}$ wide, $3 \mathrm{~m}$ 
deep and $3 \mathrm{~m}$ high. Over 20 millions pixels are displayed using a video projection system combining thirteen 3D HD Barco projectors. The tracking system is composed of 16 ARTTRACK2 infrared cameras by $\mathrm{ART}^{2}$. Sound is spatially rendered using a 10.2 sound system with speaker $\mathrm{s}$ or a 5.1 headset system, controlled by the user's position.

Immersia is a key node of the FP7 European Project Visionair [2] which goal is to create a European infrastructure that should be a unique, visible and attractive entry towards high-level visualisation facilities for Virtual Reality, Scientific Visualisation, Ultra High Definition, Augmented Reality and Virtual Services. These facilities, distributed across about twenty countries in Europe, are open and easily accessible to a wide set of research communities. Both physical access and virtual services are provided by the infrastructure. Full access to visualization-dedicated software is offered through call for projects, while physical access to high level platforms will be partially accessible to other scientists, free of charge, based on the excellence of the project submitted. Immersia hosted three scientific projects from the beginning of Visionair, one in ergonomics, one in sport training, and one studying 3D sound perception in a large virtual environment.

\section{French National Days of Archaeology}

The National Days of Archaeology are annually organized by the French Ministry for Culture and Communication, and coordinated by the National Research Institute in Preventive Archaeology (Inrap). This three-day event aims at presenting to a large public the diversity of archaeology work through novel exhibitions and initiatives. All over the country, visits of archaeological sites, conferences, exhibitions, historical reconstitutions are proposed to discover local cultural Heritage.

The 2013 National Days of Archaeology, taking place in June, was the fourth edition of the event. It gathered 1167 local events and attracted around 120.000 visitors.

\section{OBJECTIVES OF THE IMMERSIA EVENT}

Among all the events of the National Days of Archaeology, the Immersia exhibition aimed at presenting the West Digital Conservatory of Archaeological Heritage project, and immersing visitors in a reconstitution of a Gallo-Roman site in virtual reality for a direct cognitive experience of the past.

The Immersia event was proposed for two days, the first one targeting only scholars. We wanted to emphasize on the scientific work behind the virtual reality reconstitution on both archaeological and computer science sides.

Our objectives were thus three-fold :

1. Communicate around our inter-disciplinary collaboration,

2. Diffuse the archaeological discoveries related to this Gallo-Roman sites, the virtual reality principles, and the interest of this technology for archaeologists work,

1 www.barco.com

2 http://www.ar-tracking.com
3. Provide people with an immersive experience of the past in our virtual reconstitution.

\section{SCIENTIFIC CONTENT OF THE IMMERSIA EVENT}

The Immersia event relied on two scientific results:

1. The archaeological results of the Bais GalloRoman site excavation;

2. The reconstitution in virtual reality of the GalloRoman site from archaeologists' discoveries.

\section{A. The Bais gallo-roman villa}

The Gallo-Roman villa of Bourg Saint-Père in Bais is located between Vitré and Janzé, in Brittany, France. The site has been excavated between 2006 and 2009 by Pouille [3]. There are no remaining buildings on the site, only foundations.

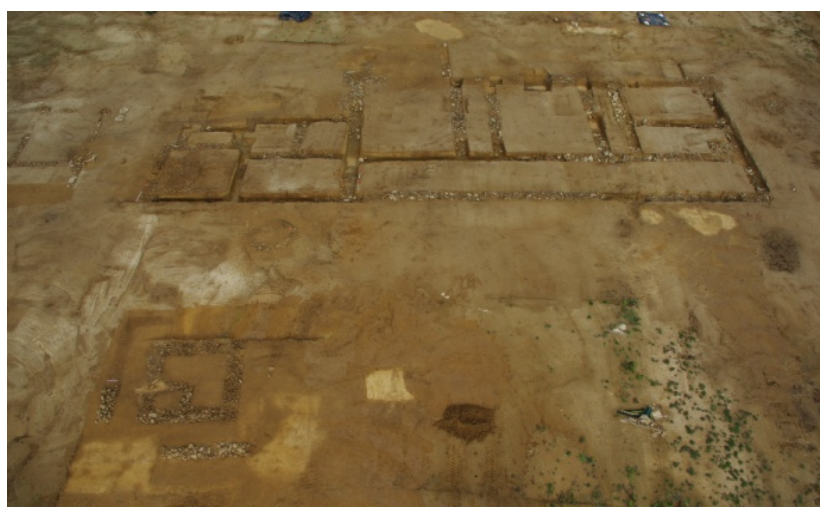

Fig. 1. Building foundations in the excavation.

The site consists in remains of a rural area with several buildings spreading over a surface of about two acres and dated from the first to the fourth century AD. The main building, the master's house, is $26 \mathrm{~m}$ long and $13 \mathrm{~m}$ large.

One of the main characteristics of the site is the unusual number of religious buildings. Archaeologists discovered two romano-celtic temples, "fana", consisting of a central cella surrounded by a covered porch with columns used for religious ceremonies, one Roman temple with a typical pediment, and one circular little building, a laraire, probably hosting the statue of a deity.

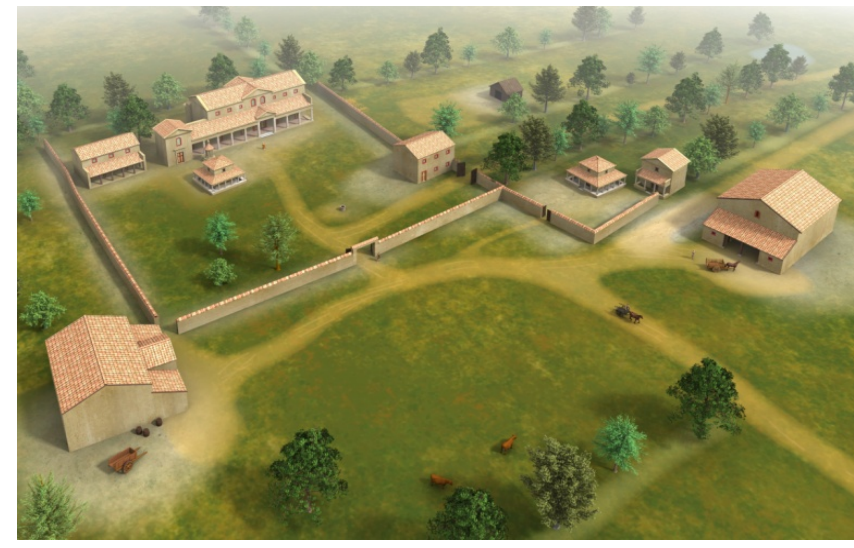

Fig. 2. The 3D reconstitution of the Bourg Saint-Père villa. 


\section{B. The VR implementation}

From the result of the excavation, an archaeologist designed a 3D model of what the site should look like. The modeling work is integrated as early as possible in the process, both to help archaeologists in their research work and to ensure the scientific relevance of the resulting $3 \mathrm{D}$ model. In order to validate the hypotheses performed in the reconstitution steps, a 1:1 immersive reconstitution was implemented by computer scientists in virtual reality, starting from the 3D model built in the previous phase by archaeologists.

The implementation used the open-source VR software OpenMASK [4]. Given the goals of the virtual reconstitution, the only interaction implemented was user navigation. More precisely, three navigation modes were proposed:

1. Thanks to the large size of the installation, the user can naturally walk on the $30 \mathrm{~m}^{2}$ of the floor screen. The images are then adapted in real-time to the user's point of view while he is moving in the environment.

2. The user can rely on the joystick of the ART flystick, a wireless device tracked by the IR cameras, to navigate in the virtual world without moving his body.

3. A set of points of interest was predefined in the virtual universe, that the user could directly access by clicking on a button of the flystick.

The resulting immersive implementation was visited by archaeologists in order to evaluate the coherency of the reconstitution. The feedback was positive and all the architectural hypotheses were validated during working sessions in Immersia : in the 3D model of the site, the arcade of the frontage seemed disproportionate. The scale 1:1 transposition allowed to confirm the hypothesis. It was also interesting to appreciate the covisibility or occlusion relations between the different parts of the villa. The question of flows between the buildings was also easier to conceive.

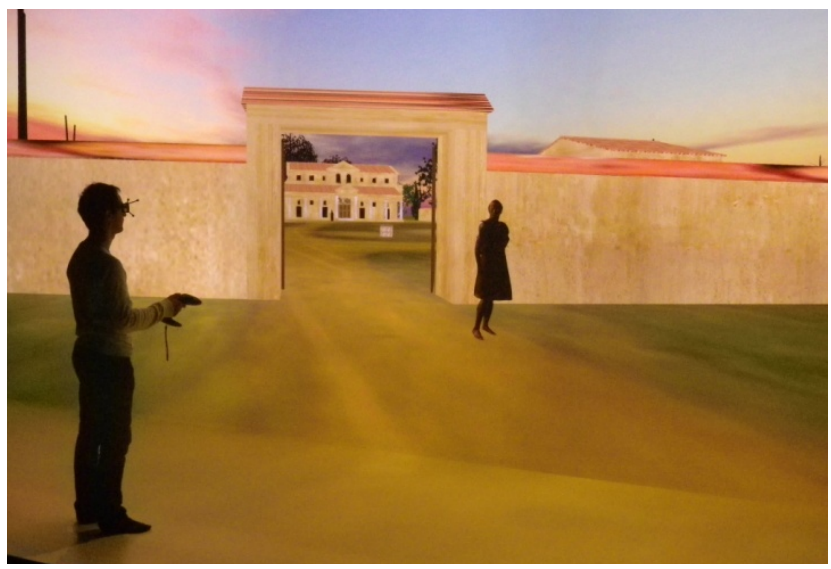

Fig. 3. The VR reconstitution of the Bourg Saint-Père villa

The application was deployed on a nine nodes cluster addressing all thirteen projectors. A tenth node handles the tracking by ART cameras, and a VRPN server, used to centralize the communication with the different interaction devices. Major technical issues to address were the distributed implementation, the rendering efficiency with respect to the resolution of the system and the stereoscopy. The execution was satisfying, with a frame rate of $60 \mathrm{fps}$, displaying more than 500.000 polygons, on a resolution of 20 millions of pixels, using quad buffer active stereoscopy.

\section{ORGANISATION OF THE EVENT}

The event was hosted in the "Espace des Technologies Innovantes", Fig. 4, a building in Rennes university campus where the Immersia platform is installed.

The Immersia event was organized in a three-step visit by groups of maximum 20 persons (see Fig. 5). The first day, the visit was booked for scholars. We received four classes, two from middle schools, and two from high schools, each class separated in two groups. The second day was open to every one, after a reservation process during the previous week. We received eight groups of 20 persons.

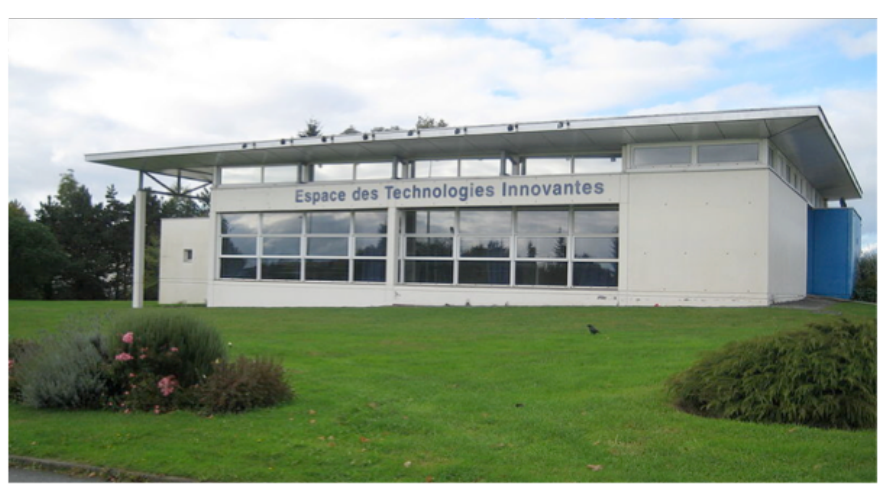

Fig. 4. "Espace des Technologie Innovantes” in Rennes, France.

First, a half-an-hour conference presented the scientific context of the work. Then the group moved to the immersive area to experience the virtual reconstitution of the GalloRoman site. At last, the group had a free time in an exhibition area.

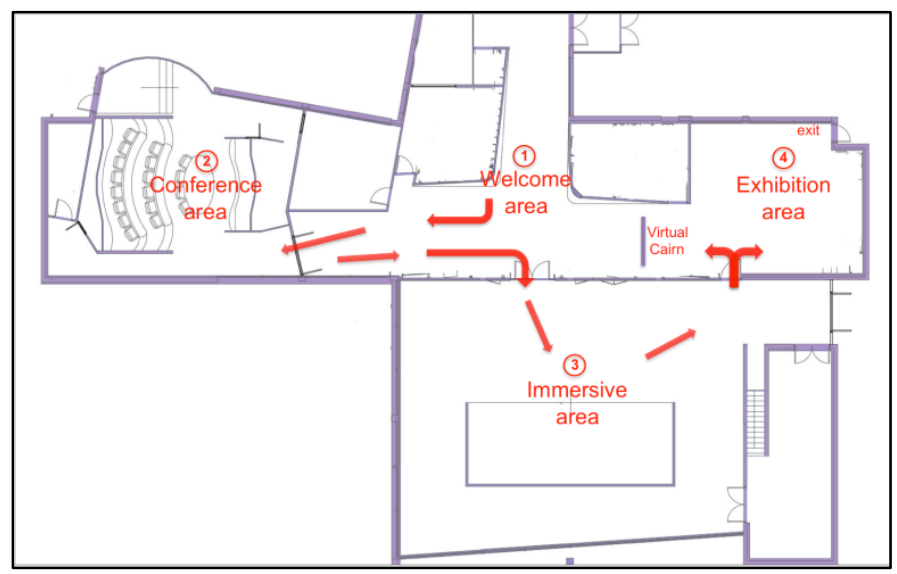

Fig. 5. Course of the Immersia event.

\section{A. Amphitheatre presentation}

The first step of the Immersia event was a conference (Fig. 6) staged in three presentations: the first presentation focused on the West Digital Conservatory of Archaeological 
Heritage, the second one introduced Virtual Reality principles and the Immersia platform, and the third one described the Gallo-Roman site and the scientific approach leading to the digital reconstitution.

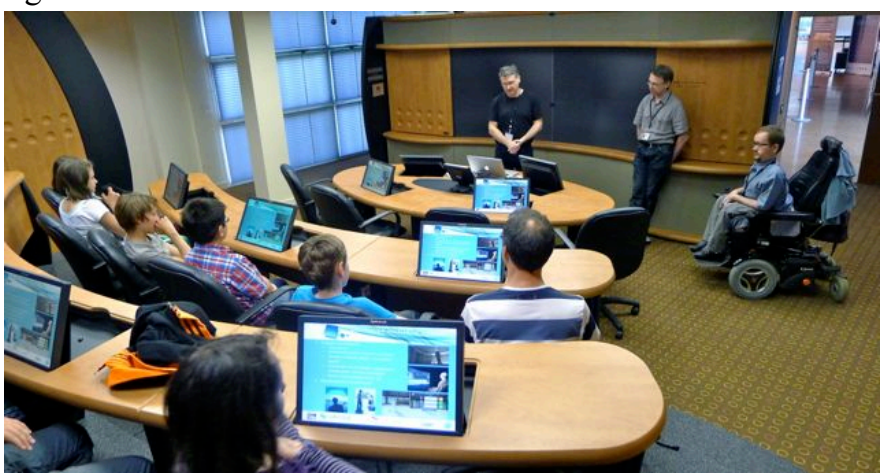

Fig. 6. Conference area.

We believe that this introduction was crucial for the visitors to understand the scientific content of the underling work and to prevent the immersive experience to be just considered as a fun entertainment.

\section{B. Immersive experience}

The immersive experience (Fig. 7) in the Immersia VR platform was obviously the most awaited for part of the event. A strong constraint of the facility is that only one person can be immersed at a time. This limitation is due to the fact that only one point of view is valid with respect to the projection on the four orthogonal screens. Indeed, this projection is computed in real-time with respect to the user's head position and orientation.

Active stereoscopy and 1:1 display drove people in a strong immersive experience in past times. Navigation was limited to five points of interest (POI), and natural walking on the scene at each POI area. The first POI was a global view of the site, 6 meter high from ground, establishing the link with the previous presentation. The second POI was located around a well, in the courtyard in front of the villa building. The third one was located in front of one fanum, inside the covered porch with the colonnade. The fourth one was placed around a statue just in front the villa. The last one was placed upstairs a wooden staircase. The well and the staircase allowed people to strongly feel the effect of 3D. The temple area encouraged people to naturally walk all along the front colonnade and discover the organization of the different buildings while moving to the sides of the fanum. The statue encountered lot of success, everybody trying to "touch" it, and walking all around it. Such experiences are out of reach with simple PC displays or even with 3D cinema screens.

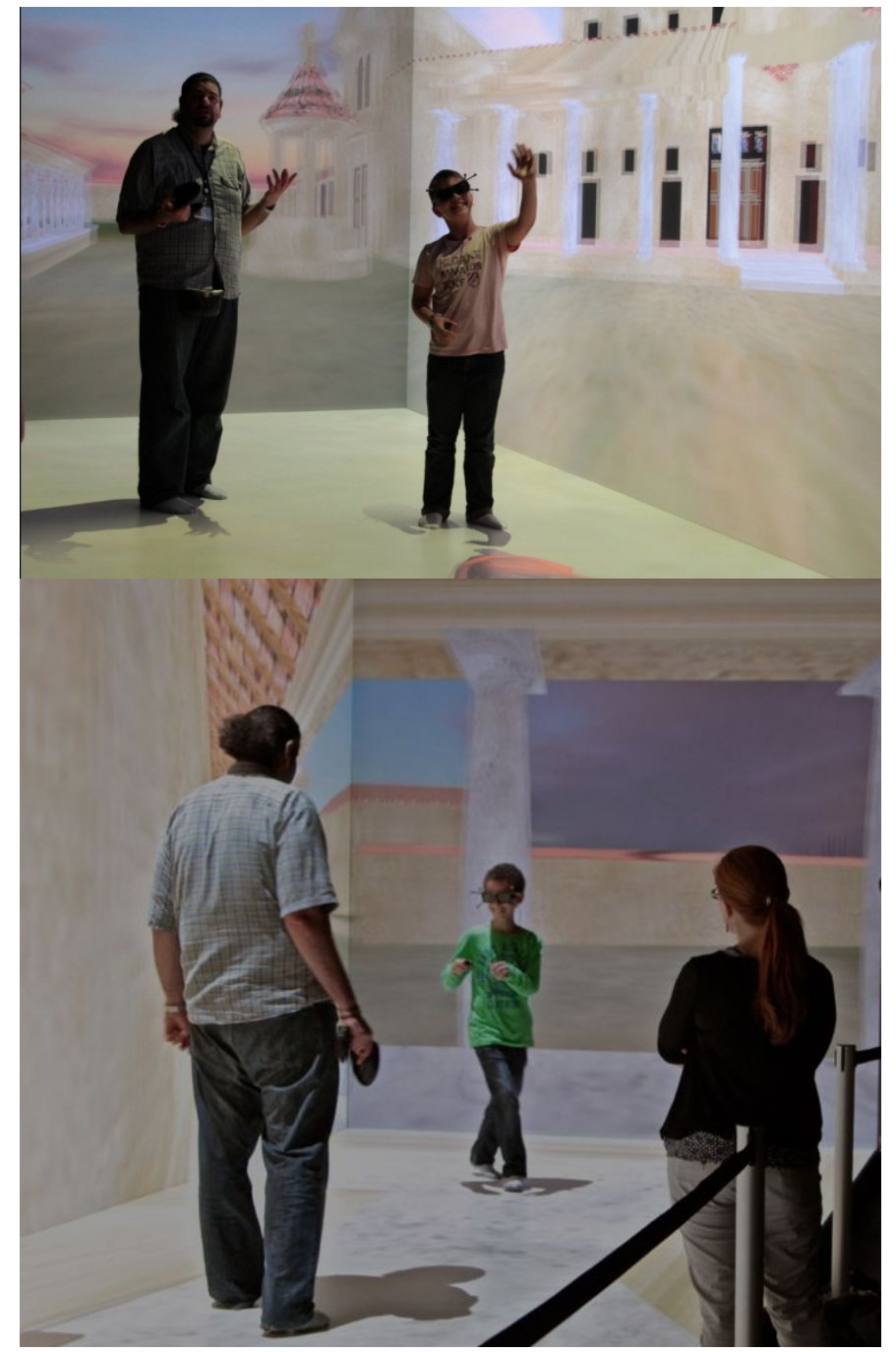

Fig. 7. Immersive area.

\section{Exhibition}

The last step was the exhibition area (Fig. 8) dedicated to the presentation of the missions and activities of Inrap.

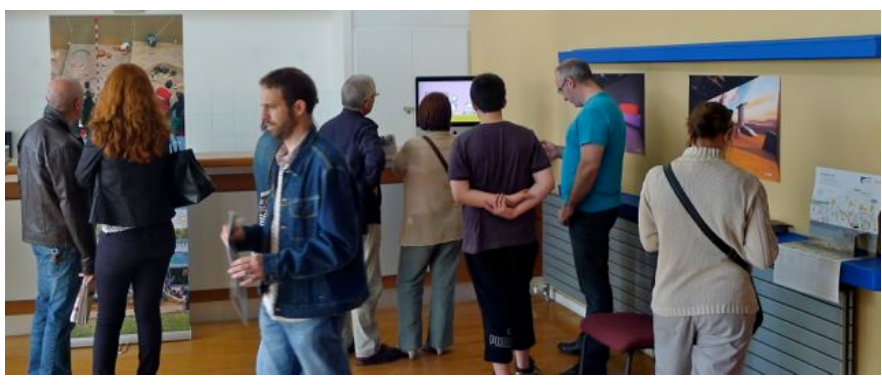

Fig. 8. Exhibition area.

A VR reconstitution of a cairn [6] was displayed on a large screen (Fig. 9). A mouse interaction allowed navigation in 3D in the central chamber of the cairn. This reconstitution is part of an ongoing WDCAH project on several Neolithic sites in Brittany. Movies on Immersia construction, Inrap activities, 
and Bais excavation were displayed on a monitor. Several rollups, posters and booklets completed the exhibition.

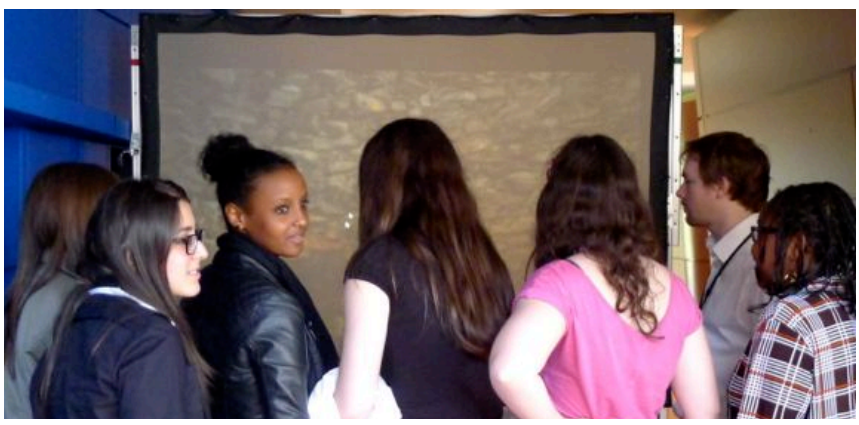

Fig. 9. The virtual cairn.

Researchers and professors from Inrap and IRISA were present in the exhibition area to exchange with visitors and answer to their questions.

At last, a guestbook was available to gather comments from visitors and collect feedback.

\section{EVENT FEEDBACK}

Collecting and analyzing feedback is a mandatory yet uneasy task. We distinguished and exploited three sources to set up an assessment of the Immersia event: (i) visitors' behavior during the event, (ii) visitors feedback from the guestbook and discussions, and (iii) feedback from the fourteen volunteers involved in the organization of these two days.

\section{A. Visitors behavior}

While the immersive time was the most awaited for part of the event, people showed obvious interest in the two other areas. Many questions occurred during the presentations in the conference area, and researchers and profesors were highly sollicited in the exhibition area. Most of these questions were relevant, especially from young scholars. The mixing of thematics from archaeology, 3D and virtual reality seemed to be well understood, despite the technicity of some aspects, may be thanks to the digital images attraction which allowed to maintain a good level of attention.

During the immersive experience, people unfamiliar with virtual reality strongly experimented the presence feeling [7], forgetting the underlying technology, trying to touch (Fig. 10) or to skirt virtual objects and being affected by vertigo (Fig. 11).

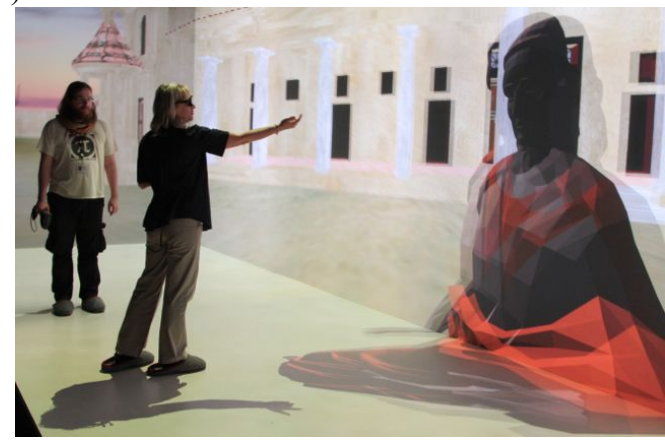

Fig. 10. Touching the past.

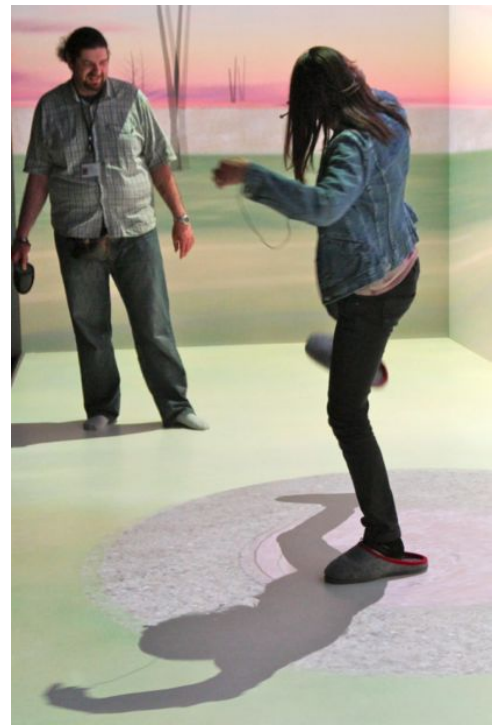

Fig. 11. Vertigo sensation.

\section{B. Visitors feedback}

The guestbook gathered many appreciative comments. Beyond the satisfaction of such messages, we noticed that several feedbacks were thankful to the scientific content, which was the most challenging goal of the event.

Visitors also appreciated the opportunity to access a highend technological environment dedicated to research. One of the recurrent questions was of course the date of the next public event in Immersia.

\section{Organisators feedback}

The event required an important preliminary organization, involving students, researchers and engineers from both computer science and archaeology laboratories, and communication departments from the tutorship institutes. The two days of the event were intense for the supervising volunteers. The global feeling was however a satisfaction of sharing their work and getting such a good feedback from visitors.

\section{DISCUSSION AND CONCLUSIONS}

\section{A. A cognitive experience}

As pointed in [15], virtual reality is closely related to cognitive infocommunications with the establishment of a communication between a real human and a virtual universe. In particular, immersive virtual reality furthers a strong communication level between the two entities by setting a "first-person" relation and enabling "cognitive presence" [12].

Virtual reality thus constitutes a useful tool for education, whose relevancy is discussed in [13]. In our case, the presentation of a disappeared cultural heritage building, immersive virtual reality was completely appropriate.

However, the immersive experience is not sufficient to allow the user to fully understand, on one hand, the archaeological discoveries in the site, such as the role of the different buildings, or the architectural hypotheses, and on the 
other hand, the underlying virtual reality concepts implemented, such as navigation, or head-tracking. In [14], five common attributes are identified for using virtual reality in architectural heritage learning : (i) content, related to the knowledge to be acquired by the user, (ii) experience, related to presence feeling, (iii) setting, concerning the immersive facility, (iv) support, relying on the accessibility of the knowledge "for all", and (v) interface which must be intuitive between the user and the virtual universe. We chose to propose a natural and intuitive immersion in the virtual site, accessible to everyone, with a preliminary presentation of the scientific content in a short conference, and a posterior oral exchange with scientists accompanied with a visual exposition. This combination of different modes (intra- and inter-cognitive) and levels (first- and third-person) of communication with the visitors allowed to acquire a progressive and deep understanding of the underlying scientific work.

\section{B. The Immersia event conlusion}

This Immersia event fulfilled its three goals. The scientific message was well understood by the visitors, the results of the underlying interdisciplinary work were greeted, and the immersive experience highly appreciated.

If the visit was restricted to the only immersive part, visitors would have been unable to apprehend the underlying scientific work, however strong were the physical feelings in the virtual world. The preliminary conference was a really valuable complement to convey accessible but essential knowledge and understanding of this experience. The exhibition part completed the event with additional information and free exchanges with researchers from both archaeology and computer science domains.

The main drawback was the restriction on the number of persons that could experience the immersive visit due to the single user at a time constraint in Immersia. The reservation list was full after only one day, while this phase was scheduled over a full week. This drawback was offset by the media repercussion of the event including two television channels, two radios, and three newspapers.

Another issue is the cost of the event due to the operating cost of the platform. For this first edition, the event was completely free of charge for the visitors. A new edition of this event may require a financial participation from the visitors.

Globally, the Immersia event was a rich experience both for the public and the organizers. In addition, this event shows how an active and fruitful collaboration between two scientific communities was able to spread joint research results to a large audience.

\section{ACKNOWLEDGMENTS}

The authors wish to thank Florent Violleau for his work on the OpenMASK implementation, Marc Christie for his kind support. They also want to thank all the volunteers of the event.
Finally, the authors thank Inrap, Université Rennes 1, UEB, Images et Réseaux cluster for their logistic or financial support.

\section{REFERENCES.}

[1] J.-B. Barreau, R. Gaugne, Y. Bernard, G. Le Cloirec, V. Gouranton, "The West Digital Conservatory of Archaeological Heritage project", in Proceedings of Digital Heritage International Congress 2013, Vol. 1, pp 547-554.

[2] A. Kopecki, U. Wössner, D. Mavrikios, L. Rentzos, C. Weidig, L. Roucoules, O. Ntofon, M. Reed, G. Dumont, D. Bündgens, A. Milecki, P. Baranyi, F. Noel, C. Masclet, M. Attene, F. Giannini, M. Spagnuolo, "VISIONAIR: VISION Advanced Infrastructure for Research", SBC Journal on 3D Interactive Systems 2, 2011, pp 40-43.

[3] G. Le Cloirec, "Bais, Le bourg St Père, proposition de restitution des volumes", in Dominique Pouille - "La villa gallo-romaine du bourg St Père à Bais (35)", DFS de fouille archéologique préventive, unpublished, Rennes, Inrap 2011

[4] D. Margery, B. Arnaldi, A. Chauffaut, S. Donikian, T. Duval, "OpenMASK: Multi-Threaded or Modular Animation and Simulation Kernel or Kit: a General Introduction”, in Proceedings of VRIC 2002, S. Richir, P. Richard, B. Taravel (eds.), Laval, France, June, 2002, pp 101110.

[5] R. Gaugne, V. Gouranton. G. Dumont, A. Chauffaut, B. Arnaldi, "Immersia, an open immersive infrastructure: doing archaeology in virtual reality", in Archeologia e Calcolatori, to appear.

[6] R. Gaugne, J.-B. Barreau, F. Cousseau, V. Gouranton, "Large-scale immersive reconstitution of a Neolithic corbel dome", VAST 2012 Int. Symp. on Virtual Reality, Archaeology and Cultural Heritage, Nov 2012, Brighton, United Kingdom. pp 1-8.

[7] M. Lombard, T. Ditton, "At the Heart of It All: The Concept of Presence.”, Journal of Computer-mediated Communication 3 (1997).

[8] C. L. Morgan, "(re)building catalhoyuk : Changing virtual reality in archaeology", Archaeologies, Journal of the World Archaeological Congress 5(3):468-487, 2009.

[9] S. Pescarin, L. Calori, C. Camporesi, M. D. Ioia, M. Forte, F. Galeazzi, S. Imboden, A. Moro, A. Palombini, V. Vassallo, L. Vico, "Back to 2nd AD AVR on-line experience with Virtual Rome Project", VAST 2008 Int. Symp. on Virtual Reality, Archaeology and Cultural Heritage, pp 109-113.

[10] K. Bale, D. Abbott, Gowigati, D. Pritchard, P. Chapman, "Linking Evidence with Heritage Visualization using a large Scale Collaborative Interface" VAST 2011 Int. Symp. on Virtual Reality, Archaeology and Intelligent Cultural Heritage, pp 121-128.

[11] C. Christou, C. Angus, C. Loscos, A. Dettori, M. Roussou, "A versatile large-scale multimodal VR system for cultural heritage visualization", VRST06 Symp. on Virtual reality software and technology, ACM, pp 133-14.

[12] W. Winn, "A conceptual basis for educational applications of virtual reality", Technical Report TR-93-9, Seattle, Washington: Human Interface Technology Laboratory, University of Washington, 1993. http://www.hitl.washington.edu/publications/r-93-9/

[13] V. S. Pantelidis, "Reasons to Use Virtual Reality in Education and Training Courses and a Model to Determine When to Use Virtual Reality", Themes in science and technology education, Special Issue, Klidarithmos Computer BooksVol.2 No 1-2, 2009, pp 59-70.

[14] J. Aida Abu Bakar, P. Shireen Jahnkassim, M. Mahmud, "User Requirements for Virtual Reality in Architectural Heritage Learning”, Int. Journal of Interactive Digital Media, Vol. 1(1), 2013.

[15] P. Baranyi, A. Csapo, "Definition and Synergies of Cognitive Infocommunications", in Acta Polytechnica Hungarica, Vol. 9, No 1, 2012. 